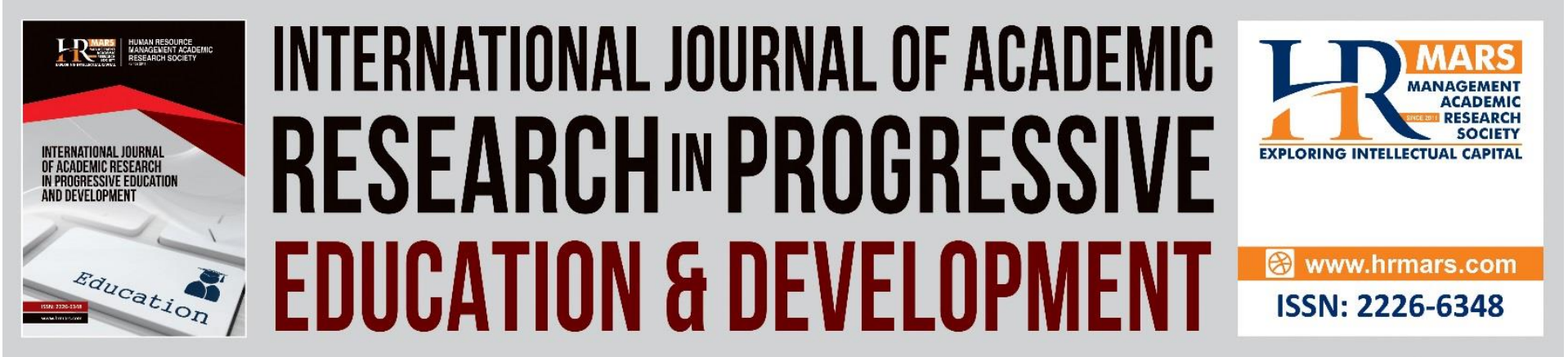

\title{
E-portfolio Implementation in Malaysian School: A Need Analysis
}

Noor Fazlina Yati Mat Razali, Jamilah Hamid \& Haslinda Hashim

To Link this Article: http://dx.doi.org/10.6007/IJARPED/v10-i4/11842

DOI:10.6007/IJARPED/v10-i4/11842

Received: 08 September 2021, Revised: 11 October 2021, Accepted: 25 October 2021

Published Online: 20 November 2021

In-Text Citation: (Razali et al., 2021)

To Cite this Article: Razali, N. F. Y. M., Hamid, J., \& Hashim, H. (2021). E-portfolio Implementation in Malaysian School: A Need Analysis. International Journal of Academic Research in Progressive Education and Development, 10(4), 60-71.

Copyright: (c) 2021 The Author(s)

Published by Human Resource Management Academic Research Society (www.hrmars.com)

This article is published under the Creative Commons Attribution (CC BY 4.0) license. Anyone may reproduce, distribute, translate and create derivative works of this article (for both commercial and non-commercial purposes), subject to full attribution to the original publication and authors. The full terms of this license may be seen at: http://creativecommons.org/licences/by/4.0/legalcode

Vol. 10(4) 2021, Pg. 60 - 71

http://hrmars.com/index.php/pages/detail/IJARPED

JOURNAL HOMEPAGE

Full Terms \& Conditions of access and use can be found at http://hrmars.com/index.php/pages/detail/publication-ethics 


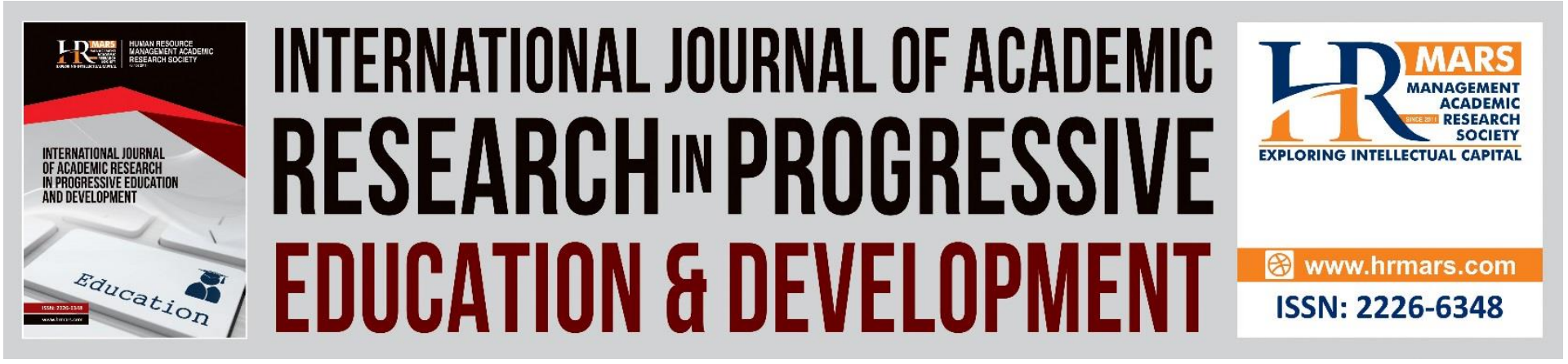

\title{
E-portfolio Implementation in Malaysian School: A Need Analysis
}

\author{
Noor Fazlina Yati Mat Razali, Jamilah Hamid \& Haslinda \\ Hashim
}

Department of Computing, Faculty of Arts, Computing and Creative Industries, Universiti Pendidikan Sultan Idris, Tanjung Malim, Perak, Malaysia.

\begin{abstract}
The uncertainty about assessing student learning outcomes is one of the concerns frequently discussed in education during the Covid-19 Pandemic. The use of technology in assessing student learning has become a new paradigm in transforming traditional assessment to digital assessment. The E-portfolio has been one of the tools that can be used to conduct digital assessments. However, E-portfolios are still uncommon among Malaysian teachers. As a reason, the purpose of this study is to identify the challenges of integrating ICT in classroom assessment, to examine current E-portfolio implementation practises among teachers, and to investigate teachers' perceptions of E-portfolio use as a digital assessment tool in teaching and learning. This is a quantitative approach that uses a set of questionnaires distributed online. The sample for this study is composed of 97 teachers who teach Asas Sains Komputer in Terengganu. The frequency, percentage, mean, and standard deviation of the data were analysed using the Statistical Package For Social Science (SPSS) version 25.0. Findings show that: i) Appropriate facilities and equipment are important in implementing ICT in classroom assessment; ii) Current practice of E-portfolio among teachers is low, and iii) Teachers have positive perceptions of using E-portfolio in assessing the Asas Sains Komputer subject. Hence, it is suggested that a module, model or guidelines be developed for teachers using E-portfolios in the classroom as a reference.
\end{abstract}

Keywords: E-portfolio, Digital Assessment, Digital Portfolio, Student Assessment, E-portfolio Implementation.

\section{Introduction}

The Malaysian Education Development Plan (PPPM) 2013-2025 is a pillar of the holistic education system in Malaysia. The national examination system and school-based assessment have been overhauled to enhance students' high-level thinking skills by providing equal access to international standard education. Under the 7th shift of PPPM, namely Information and Communication Technology (ICT), must be utilised to improve the quality of teaching and learning. ICT integration as a teaching medium is significant and beneficial to teachers and students (Elmahdi et al., 2018; Dlab et al., 2015). Information Technology in education can 
make learning effective, and students tend to think creatively and generate ideas better (Masharah, 2017; Nidzam, 2016).

The Ministry of Education Malaysia has introduced technology-based learning, where one of the subjects introduced is Asas Sains Komputer (ASK). The Kurikulum Standard Sekolah Menengah (KSSM) for ASK is a continuation of Information and Communication Technology subjects that have been introduced at the primary school level and replaces the Information and Communication Technology Literacy (ICTL) program in secondary schools (Curriculum Development Division, 2017). The goal of KSSM ASK is to provide students with computational thinking with the hope of contributing to the country in the future. In addition, KSSM ASK emphasises assessing students' knowledge and skills to ensure that teaching and learning objectives are achieved based on the set goals.

Faced with the current globalisation, to ensure that all students acquire knowledge and skills relevant to the needs of IR 4.0, the conventional examination-oriented education system needs to change by integrating information technology in teaching, learning and assessment. From the context of assessment, Saedah (2020) stressed the need to incorporate information technology in student assessment to reduce reliance on pen and paper tests that are seen as irrelevant now. Reqan (2018); Ravikumar (2015) view that examination-based assessment does not comprehensively describe student achievement's potential, skills, and development.

The COVID-19 pandemic has changed the world education landscape, resulting in the need for online learning to become a priority to ensure the continuity of teaching and learning. The new normals in this situation also affect the assessment of student learning. Therefore, the online form of assessment is an alternative approach to the existing traditional assessment. Online assessment systems have long been in use over the past few years, and their service has facilitated teachers in identifying students who need special attention (Scapo \& Molnar, 2018). One digital assessment tool that supports teaching, learning, assessment, and professional development is the E-portfolio. Barrett (2005) defines an electronic portfolio as a teaching tool that allows teachers or students to collect and organise portfolio artefacts in various media (audio, video, graphics, text) and use hypertext links to link evidence-based outcomes and goals or standards. E-portfolios serve as personal digital records that store a collection of evidence of student learning, performance or progress of student learning (Xe et al., 2019).

Using an E-portfolio as an authentic assessment greatly helps teachers manage and store evidence of student assessment in a more organised manner. In addition to serving as a place for evident storage of learning, Slepcevic-Zach and Stock (2018) argue that using E-portfolio can provide a meaningful platform in education to encourage self-reflection and development of student competence learning. Therefore, Misdi (2020); Alrefaie et al (2020) recommend that E-portfolio should be considered an alternative form of assessment as it can serve as an authentic assessment tool to empower continuous learning.

Based on the literature review, many studies have discussed implementing E-portfolios, especially at the university level. An E-portfolio is an approach or tool that is very suitable to be applied in teaching and learning. E-portfolio supports lifelong learning (Kwok \& Hui, 2018; 
Rezguia et al., 2017), shapes skills high-level thinking (Jager, 2019; Lukitasari, Handhika, \& Murtafiah, 2018), supporting assessment activities (Habeeb \& Ebrahim, 2019; McDonald et al., 2018; Rezguia et al., 2017), performing reflection on learning (Hsu, 2020; Kwok \& Hui, 2018; Roberts et al., 2016), collaborative, active learning and self -directed learning (Tur et al., 2019). Studies conducted by previous scholars have proven that E-portfolio has advantages in terms of development and student achievement. Therefore, E-portfolio is seen as very suitable to be applied in teaching and learning.

Recognising the effectiveness of the use of E-portfolio in education, especially at the school level, the Malaysian Innovation Agency (AIM), in collaboration with the Ministry of Education Malaysia, conducted a pilot project on the use of E-portfolio on ten selected secondary schools implemented in 2019 (The Star, 2018). Although there are studies conducted at the school level, the research is still in its infancy and can not provide concrete data on the use of E-portfolio at the school level. For this reason, the researcher conducted this study based on the following objectives:

i. To Identify issues and challenges of integrating ICT in classroom assessment.

ii. To examine the current practice of E-portfolio Implementation among teachers.

iii. To examine teachers' perceptions of E-portfolio as a digital assessment tool in teaching and learning.

\section{Methodology}

Research methodology is a systematic approach in research to obtain information related to the research conducted. The quantitative approach is based on a survey conducted on Asas Sains Komputer (ASK) teachers for this study. Researchers often use surveys because of their comprehensive use and quickly collect information from respondents (Chua, 2013).

The process of selecting respondents in this study is to use the purposive sampling method. Respondents in this study consisted of teachers who teach ASK subjects in four districts in Terengganu. The population of teachers involved was 128. Based on the sample size proposed by Krejcie and Morgan (1970), for a population of 128 respondents, the appropriate sample size was 97 . Thus, the sample of this study involved 97 teachers teaching ASK subjects as the respondents.

The research instrument used in this study was adapted from Samaa and Khadeegha (2019) ; Nidzam (2016). Besides, the formation of the questionnaire also refers to the literature review and discussions among researchers. The research instrument is divided into four sections, namely; Section A: Respondent Demographics, Section B: Integration of ICT in Classroom Assessment, Section C: The Use of E-portfolios in Teaching and Learning, D: Perceptions the use of E-portfolio in ASK subjects, and Section E; Software Selection Using E-portfolio. A 5point Likert scale is used for sections $B, D$, and $E$ to see respondents' consent feedback on the items presented, while section $C$ is a semi-structured question to obtain information on the implementation E-portfolio. Questionnaires were distributed to respondents online.

To determine the reliability of the instrument, a pilot study was conducted before the actual research was implemented. Before the questionnaires were distributed to the respondents, the researchers distributed questionnaires to five experts to assess the content, 
appropriateness and clarity of the language used in the study context. The results of the expert review found that the questionnaire produced is suitable for use in this study and meets the objectives of the study to be achieved. A pilot study was conducted on 30 respondents who were not involved as a sample of the actual research. Chua (2013); Arsyathamby \& Arumugan (2013) argue that the ideal Cronbach's Alpha value must exceed 0.7. The pilot study's findings showed that the overall reliability of the questionnaire based on Cronbach's Alpha value was 0.876 .

The descriptive statistical data analysis described the frequency, percentage, standard deviation, and mean used for study reporting. Statistical Package For Social Science (SPSS) version 25.0 was used to analyse the data. Descriptive analysis was performed based on the interpretation of the mean score presented by Ghazali and Sufean (2016), which contains four levels, namely low (1.00-2.00), medium-low (2.01-3.00), medium-high (3.01 - 4.00), and high (4.01 - 5.00).

\section{Findings}

The findings of this study discuss the issues of ICT implementation in student assessment, the use of E-portfolio in teaching and learning, teachers' perceptions of the use of E-portfolio and software recommendations for implementing E-portfolio. Therefore, the discussion of the findings is as follows:

\section{i. Demographic Analysis of the Respondents}

Based on the survey conducted, the demographics of the respondents were recorded, such as gender, age and experience teaching ASK subjects. The analysis of respondents' demography recorded 97 respondents involved 70 female respondents $(72.2 \%)$, the remaining 27 male respondents represented $27.8 \%$. As for the experience teaching the ASK, the finding showed that $63.9 \%(n=62)$ of respondents have teaching experience for 3-4 years. In addition, the results also showed 20 respondents (20.6\%) have experience teaching ASK for more than five years. The remaining nine respondents (9.3\%) have experience teaching ASK for 1-2 years, while six (6.2\%) have experience teaching ASK subjects less than one year.

\section{ii. Integration of ICT in Classroom Assessment}

There are five items to identify the issue of ICT integration in the classroom assessment. Table 5 displays the results of descriptive statistics on ICT integration issues in classroom assessment.

Based on table 1, the mean interpretation is high, with an overall mean value of 4.15 (sd = 0.81). Item A2 showed a moderately high level, while item A4 was high with a mean score of $4.29(\mathrm{sd}=0.80)$. This result indicates that the provision of infrastructure facilities that include appropriate hardware and software equipment is essential. Its purpose is to guarantee that ICT integration in classroom assessment is effectively executed. 
Table 1: Issues of ICT Integration in classroom assessment

\begin{tabular}{|c|c|c|c|c|}
\hline Code & Item & Mean & $\begin{array}{l}\text { Standard } \\
\text { deviation }\end{array}$ & Interpretation \\
\hline A1. & $\begin{array}{l}\text { Producing technology-assisted } \\
\text { instructional materials requires a } \\
\text { devoted amount of time. }\end{array}$ & 4.14 & 0.71 & High \\
\hline $\mathrm{A} 2$. & $\begin{array}{l}\text { Good ICT abilities are necessary for } \\
\text { classroom } \\
\text { management. }\end{array}$ & 3.95 & 0.87 & Medium-high \\
\hline A3. & $\begin{array}{l}\text { Support from school administrators } \\
\text { is essential to integrate ICT in } \\
\text { classrooms, especially for classroom } \\
\text { assessment. }\end{array}$ & 4.11 & 0.83 & High \\
\hline A4. & $\begin{array}{l}\text { A conducive environment is } \\
\text { required to integrate ICT in } \\
\text { classroom assessment. }\end{array}$ & 4.29 & 0.80 & High \\
\hline A5. & $\begin{array}{l}\text { Professional development training } \\
\text { needs should be exposure to } \\
\text { increase knowledge to integrate ICT } \\
\text { in classroom assessment. }\end{array}$ & 4.25 & 0.83 & High \\
\hline & Overall & 4.15 & 0.81 & High \\
\hline
\end{tabular}

\section{iii. The use of E-portfolios in Teaching and Learning}

A survey conducted on 97 respondents found that only $28(29 \%)$ respondents had ever used E-portfolio in teaching and learning. The remaining $69(71 \%)$ respondents have never used Eportfolio. Next, the analysis of findings related to using E-portfolio among 28 respondents who use E-portfolio. For this purpose, the researcher has classified into several themes regarding the purpose of using an E-portfolio based on the answers given by respondents. Referring to Figure 1, 68\% of respondents use E-portfolio for learning and assessment, 21\% for assessment purposes only, $7 \%$ for learning purposes only, while only $4 \%$ of respondents stated that they use E-portfolio for career development purposes. All respondents agreed that the use of an E-portfolio should be continued and disseminated to all teachers and students.

Next, the analysis of the study findings on the factors that cause teachers not to use Eportfolio is summarised in Figure 2. "No disclosure on the use of E-portfolio" contributed the highest percentage of $29 \%$ to the factor of teachers not using E-portfolio in teaching and learning. Besides, no guidance and reference $(28 \%)$ on the use of E-portfolio is also a significant factor in teachers' lack of use of E-portfolio. Alternatively, teachers stated they used conventional methods, such as worksheets, quizzes and traditional portfolios, to assess student learning in the subject of Asas Sains Komputer. 


\section{PURPOSE OF USING E-PORTFOLIO}

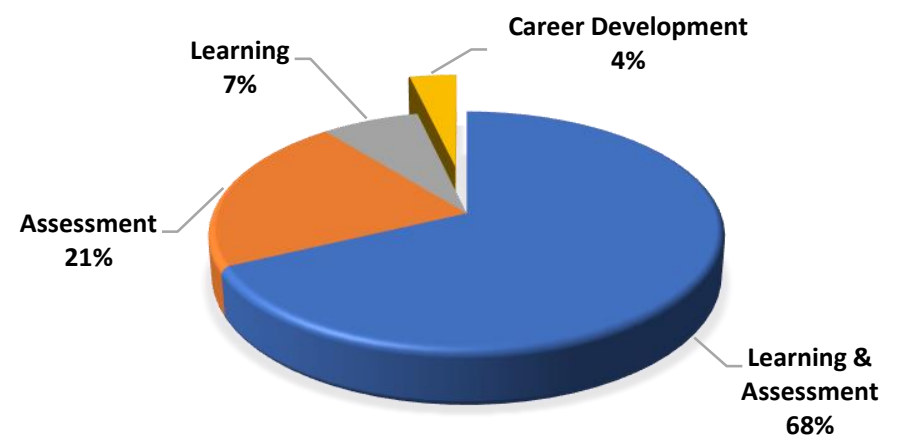

Figure 1: Percentage of Purpose of E-portfolio Use

\section{FACTORS NOT USING E-PORTFOLIO IN TEACHING AND LEARNING}

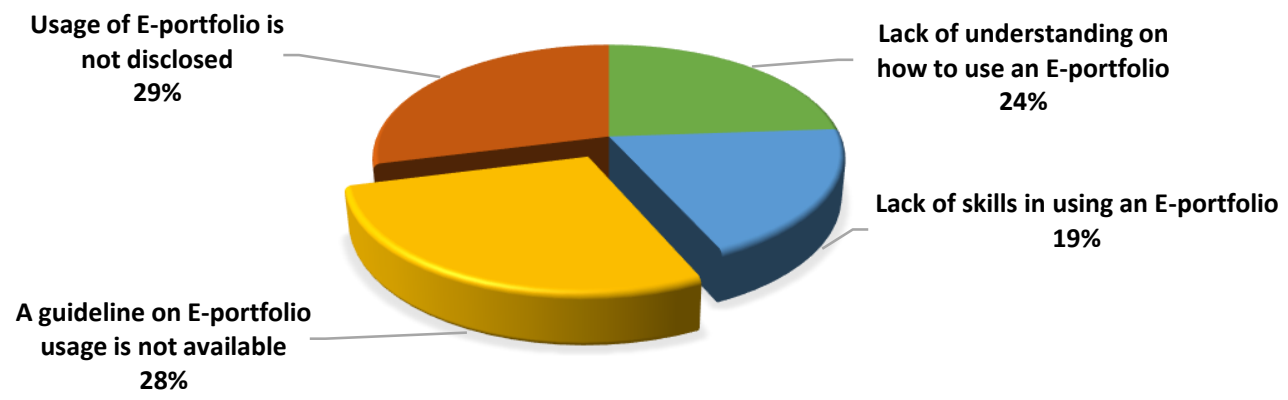

Figure 2: Percentage of Factors not using E-portfolio

Nevertheless, the respondents stressed that there is no model or guideline on using Eportfolio that can be used as a reference for teachers to implement E-portfolio in teaching and learning. $87 \%$ of respondents agreed there is a need to develop a model or guideline as a reference for using E-portfolios.

\section{iv. Teachers' Perceptions of the Use of E-portfolios in ASK Subjects}

Table 2 displays a descriptive analysis of teachers' perceptions of the use of E-portfolios in ASK subjects. The overall mean score value for the teacher perception construct was 4.20 (sd $=0.63$ ), indicating a high mean interpretation. Findings display item B9 with a mean value of 4.29 and a standard deviation of 0.59. To put it simply: E-portfolios are ideal for deployment in ASK as a tool for documenting student work. While items B7 (sd $=0.68)$ and B8 $(s d=0.60)$ each have the same mean score value of 4.12. These findings showed the respondents agree that using E-portfolio in ASK is relevant. As a result of its optimal application, it can also enhance pupils' creativity and high-level thinking skills. 
Table 2: Mean Score of teachers' perceptions on the use of E-portfolio in ASK subjects.

\begin{tabular}{|c|c|c|c|c|}
\hline Code & Item & Mean & $\begin{array}{l}\text { Standard } \\
\text { deviation }\end{array}$ & Interpretation \\
\hline B1. & $\begin{array}{l}\text { It can be an alternative assessment tool } \\
\text { for } 21 \text { st-century learning to traditional } \\
\text { assessment }\end{array}$ & 4.22 & 0.63 & High \\
\hline B2. & The use of E-portfolios is flexible & 4.18 & 0.56 & High \\
\hline B3. & $\begin{array}{l}\text { The use of E-portfolios is highly } \\
\text { interactive in teaching and learning }\end{array}$ & 4.15 & 0.60 & High \\
\hline B4. & $\begin{array}{l}\text { Can help improve the use of different } \\
\text { creative tools in the assessment }\end{array}$ & 4.22 & 0.54 & High \\
\hline B5. & $\begin{array}{l}\text { Appropriate mobile technology used in } \\
\text { student assessment }\end{array}$ & 4.18 & 0.61 & High \\
\hline B6. & $\begin{array}{l}\text { Able to make rapid assessments of } \\
\text { student learning }\end{array}$ & 4.19 & 0.62 & High \\
\hline B7. & Able to increase student creativity & 4.12 & 0.68 & High \\
\hline B8. & $\begin{array}{l}\text { Able to improve students' high-level } \\
\text { thinking skills }\end{array}$ & 4.12 & 0.60 & High \\
\hline B9. & $\begin{array}{l}\text { Can help the process of documenting } \\
\text { student work more systematically }\end{array}$ & 4.29 & 0.59 & High \\
\hline B10. & Able to monitor student work & 4.25 & 0.61 & High \\
\hline B11. & $\begin{array}{l}\text { Able to open up opportunities to use } \\
\text { technology in the classroom }\end{array}$ & 4.23 & 0.67 & High \\
\hline & Overall & 4.20 & 0.63 & High \\
\hline
\end{tabular}

\section{v. E-portfolio Implementation Software Suggestions}

As shown in Table 3, the mean score interpretation shows the recommendation software to use E-portfolio is at a medium-high level with a mean score of 3.32 and a standard deviation of 0.99. In the research, the Google Classroom platform had the highest mean and was the major suggestion for using E-portfolio in ASK with $4.26(\mathrm{sd}=0.70)$. The item with a mediumhigh mean are Blog (mean $=3.39$ and $s d=1.11)$, Facebook (mean $=3.33$ and $s d=1.10)$, and Edmodo (mean $=3.13$ and $s d=1.05$ ). Other items Wikis (mean $=2.96$ and $s d=1.08$ ) and Mahara (mean $=2.93$ and $s d=1.05$ ) recorded medium-low mean scores. 
INTERNATIONAL JOURNAL OF ACADEMIC RESEARCH IN PROGRESSIVE EDUCATION AND

DEVELOPMENT

Vol. 10, No. 4, 2021, E-ISSN: 2226-6348 @ 2021 HRMARS

Table 3: Suggestion of software for the use of E-portfolio

\begin{tabular}{lllll}
\hline Code & Item & Mean & $\begin{array}{l}\text { Standard } \\
\text { deviation }\end{array}$ & Interpretation \\
\hline C1. & Blog & 3.39 & 1.11 & Medium-high \\
C2. & Mahara & 2.93 & 1.05 & Medium Low \\
C3. & Wikis & 2.96 & 1.08 & Medium Low \\
C4. & Google Classroom & 4.26 & 0.70 & High \\
C5. & Edmodo & 3.13 & 1.05 & Medium-high \\
C6. & Facebook & 3.33 & 1.10 & Medium-high \\
\hline & Overall & $\mathbf{3 . 3 2}$ & $\mathbf{0 . 9 9}$ & Medium-high
\end{tabular}

\section{Discussion}

In the process of integrating ICT in the classroom, various issues need to be addressed. This study clearly shows that appropriate facilities and equipment are essential in implementing ICT in classroom assessment. In addition, the study's findings indicate that the challenge of using ICT by teachers in student assessment are teachers' readiness with skills and knowledge, the support of administrators and infrastructure needs are also the key factors. Additionally, to ensure learning continuity, teachers must enhance their pedagogical skills, information technology skills, and innovation, as the concept of online learning is essential for students to continue the learning process. Teachers should use ICT to improve the quality of teaching and learning to keep pace with technological advancements, as stated in the PPPM 20132025. Therefore, teachers need advanced training in using various ICT tools to make students' assessments more systematic (Vorotnykova and Zakhar, 2021) to realise ICT implementation in education.

From the aspect of the use of E-portfolio, it can be concluded that the use of E-portfolio among teachers is still low. This is because the use of E-portfolio is still a relatively new trend in developing countries (Mpho-Entle and Patience, 2021), and teachers have not been exposed to E-portfolios extensively. Furthermore, with the increasing workload of teachers, they lack time to integrate ICT in the assessment of students and subsequently implement an E-portfolio. Due to the lack of knowledge and skills of using E-portfolios, teachers are still tied to the conventional assessment methods available to assess student learning. Ideally, the practice of lifelong learning should be taught to every teacher. This means that teachers need to equip themselves with adequate knowledge and skills to use the tools and exemplify Eportfolios. Besides that, the teaching experience factor enables teachers to explore tools that support the facilitation and improvement of teachers' skills in online learning, especially the usage of E-portfolios. However, it is undeniable that the initiatives taken by some teachers to explore the use of E-portfolios will open up space for more in-depth studies on the implementation of E-portfolios at the school level. As a result, they proposed guidelines or an E-portfolio model that should be developed as a reference so that the usage of an e-portfolio may be spread to all instructors and students. 
Overall, the results indicate a positive perception among teachers towards the use of Eportfolio in ASK. They showed a positive response in implementing E-portfolio in teaching and learning. The results show that apart from the E-portfolio can systematically document students' work, and teachers also argue that E-portfolio can be used as an alternative assessment tool to traditional assessment. Moreover, E-portfolio-based assessment is a valuable reflection tool (Hsu, 2020; Kwok \& Hui, 2018), supporting collaborative learning and self-directed learning (Tur, Urbina, \& Forteza, 2019) in education. Teachers emphasised that there were no modules and guidelines provided, making it difficult for them to determine what criteria or elements were needed to be referenced in using the E-portfolio as a digital assessment tool. Teachers agree that E-portfolios should be used as an assessment tool in upto-date learning because they are flexible, help to document student learning more systematically and efficiently. Especially in Malaysia, this situation is very encouraging to implement E-portfolio as a digital assessment tool in schools.

Based on the study results, Google Classroom is the main choice of teachers to be one of the platforms for implementing E-portfolio at the school level. Google Classroom helps implement the virtual learning process by creating, distributing and grading student assignments more efficiently and meaningfully (Swita \& Heri, 2019; Sukmawati, 2020). Therefore, the Ministry of Education Malaysia initiative to introduce Google Classroom as a virtual learning platform at the school level since 2019 has been synonymous with teachers. However, teachers need to be exposed to use other software in implementing E-portfolios. This can indirectly create a diversity of teaching methods and assessment of students while strengthening the process of building knowledge and skills of teachers in virtual learning.

\section{Conclusion and Recommendation}

Pandemic Covid-19 has transformed face-to-face teaching and learning activities into a form of online learning. Faced with this situation, the use of technology in education becomes an important requirement. Thus, E-portfolio can be considered a digital assessment tool that can use as an alternative approach to assessing students in the classroom.

In conclusion, it can be concluded that there is a need to expand and introduce the use of Eportfolio in the subject of Asas Sains Komputer. This is supported by the study's findings, which showed that teachers' perceptions of E-portfolio as a digital assessment tool were high. Although teachers have a high perception of E-portfolios, they still lack the appropriate skills, knowledge, and platform to implement E-portfolio. Continuing Professional Development (CPD) training should be provided to teachers to improve assessment skills and exposure to the latest technology in education. Therefore, school administration should provide in-house training to teachers to enhance their understanding of 21st-century technological skills to meet current needs, in line with the $4 \mathrm{C}$ concept (Creative, Critical, Collaborative, and Communication).

Finally, it is recommended that future researchers conduct more research to design and develop modules, models, prototypes, or E-portfolio systems to help teachers apply digital assessment in teaching and learning practices. 
DEVELOPMENT

Vol. 10, No. 4, 2021, E-ISSN: 2226-6348 ㄷ 2021 HRMARS

\section{Acknowledgement}

The first author would like to express special thanks to the Ministry of Education Malaysia for the scholarship. We would also like to thank committee members of ICEHTR 2021.

\section{Corresponding Author}

Noor Fazlina Yati binti Mat Razali

Faculty of Arts, Computing and Creative Industries Universiti Pendidikan Sultan Idris, Tanjung Malim, Perak, Malaysia.

Email: fazlinamr2011@gmail.com

\section{References}

Afishata, M. A., \& Abdulai, A. (2019). Editorials: Using effective assessment to improve teaching and learning. Journal for Researching Education Practice and Theory, 1-3.

Akleh, Aamal, \& Wahab, A. R. (2020). Effectiveness of Course Portfolio in Improving Course Quality at Higher Education. International Journal of Higher Education, 9 (3): 39-48.

Alrefaie, Z., Hassanien, M., \& Al-Hayani, A. (2020). Monitoring Online Learning During COVID19 Pandemic; Suggested Online Learning Portfolio (COVID-19 OLP). MedEdPublish, 9(1).

Arsaythamby, V., \& Arumugam, R. (2013). Kaedah Analisis \& Interpretasi Data. Sintok Kedah, Malaysia: UUM Press.

Azliza, M., Othman, L., Eshah, S. M., Razmawaty, M., Salzuriawani, R., \& Fazlin, L. K. (2018). Assessing Student Teachers' Soft Skills Using Rubrics In E-Portfolio. International Journal Of Academic Research In Business And Social Sciences, 1245-1255.

Barrett, H. C. (2005). electronicportfolios.org. Retrieved from electronicportfolios.org: http://www.electronicportfolios.org/reflect/whitepaper.pdf

Barrett, H. C. (2007). Researching electronic portfolios and learner engagement: The REFLECT Initiative. INTERNATIONAL READING ASSOCIATION, 436-449.

Chua, Y. P. (2013). Kaedah Penyelidikan, Edisi Kedua. Malaysia: McGraw Hill.

Dlab, M. H., Katic, M. A., \& Candrlic, S. (2015). Ensuring Formative Assessment In E-Course With Online Tests. The 10th International Conference On Computer Science \& Education (pp. 322-327). Fitzwilliam College: Cambridge University.

Elmahdi, I., Al-Hattami, A., \& Fawzi, H. (2018). Using Technology For Formative Assessment To Improve Students' Learning. The Turkish Online Journal Of Educational Technology, 182-188.

Hsu, C. (2020). E-portfolio As A Final Assessment For A Graduate Online Course in Pandemic. American Journal of Humanities and Social Sciences Research (AJHSSR), 99-104.

Jager, T. D. (2019). Impact Of Eportfolios On Science Student-Teachers' Reflective Metacognitive Learning And The Development Of Higher-Order Thinking Skills. Journal Of University Teaching \& Learning Practice, 1-17.

Krejcie, R. V., \& Morgan, D. (1970). Determining Sample Size For Research Activities. Educational and Psychological Measurement. 607-610.

Kwok, L., \& Hui, Y. (2018). The Role Of E-Portfolio For Smart Life-Long Learning. Smart Innovation, Systems And Technologies (pp. 327-356). Smart Universities: Springer.

Misdi, M. (2020). E-Portfolio As an Authentic Learning Assessment in response to Covid-19 Outbreak in Indonesian Higher Education: Toward Critical Student-Writers. Research and Innovation in Language Learning, 3(2), 158. 
Nidzam, M. Y. (2016). Pembangunan Model Kurikulum M-Pembelajaran Teknologi Dalam Pengajaran dan Pembelajaran Di IPG. Tesis PhD: Universiti Utara Malaysia.

Masharah, N. H. (2017). Model Kompetensi Guru Pengaturcaraan Berasaskan Sistem Pendidikan Di Malaysia. Tesis Phd: Universiti Pendidikan Sultan Idris.

Ravikumar, A. K. (2015). Amalan Pentaksiran Dalam Pdp Kurikulum Standard Sekolah Rendah (Kssr) Di Sekolah Kluster. Jurnal Penyelidikan Dedikasi, 1-17.

Rezqan, N. F. (2018). The Significance Of Portfolio Assessment In EFL Classroom. LENTERA Jurnal Ilmiah Kependidikan, 13(1), $53-62$.

Samaa, A. G., \& Khadeegha, A. (2019). Exploring Teacher Perceptions of Using E-portfolios in Public Schools in the United Arab Emirates. International Journal of Education \& Literacy Studies, 180-191.

Scapo, B., \& Molnar, G. (2018). Assessment-Based, Personalized Learning In Primary Education. Proceedings of 12th Edition Of The International Forum On Knowledge Asset Dynamics (pp. 283-292). St. Petersburg: St. Petersburg University.

Sukmawati. (2020). Implementasi Pemanfaatan Google Classroom Dalam Proses Pembelajaran Online Di Era Industri 4.0. Jurnal Kreatif Online, 8(1), 39-46.

Swita, A. H., \& Heri, P. (2019). Pemanfaatan Google Classroom Sebagai Media Pembelajaran Online Di Universitas Dian Nuswantoro. WACANA, 18(2), 225-233.

Tur, G. U. S., \& Forteza, D. (2019). Rubric-Based Formative Assessment In Process Eportfolio. Digital Education Review (35), 18-35.

Vorotnykova, I. P., \& Zakhar, O. H. (2021). Teachers' Readiness To Use E-Portfolios. Information Technologies and Learning Tools, Vol 81, No 1. 